\title{
ENHANCING ENGLISH VOCABULARY THROUGH THE USE OF SNAKE AND LADDER MEDIA FOR 4 TO 6-YEAR-OLD CHILDREN
}

\author{
Murtisari Yemima \\ Universitas Kristen Satya Wacana \\ 272014002@student.uksw.edu \\ Lanny Wijayaningsih \\ Universitas Kristen Satya Wacana \\ lanny.wijaya@staff.uksw.edu \\ Mozes Kurniawan \\ Universitas Kristen Satya Wacana \\ mailbox.mozeskurniawan@gmail.com
}

\begin{abstract}
This study aims to improve the English vocabulary of 4 to 6-year-old children at TK Pertiwi 29 Semarang. This research includes classroom action research using snake and ladder media. The research subjects in this study were 20 students from kindergarten group B. Data collection techniques were observation, interview and discussion to classroom teachers and principals, as well as documentation. The research instrument used in this research was observation sheet in the form of checklist. The analysis is using observation data calculation derived from children's achievement with passing grade standard previously determined. The result of this study showed the improvement of percentage from pre-cycle that is $52 \%$, cycle I, which is $59 \%$ and $77 \%$ in cycle II. Snake and ladder media used in English language learning gradually increase children's vocabulary.
\end{abstract}

Keywords: Board Game, Childhood, English Education, Snake and Ladder, Vocabulary

\section{INTRODUCTION}

In preparing for quality education in the future, education for children is necessary because that is the basis of personal formation of human who has potency to develop a country. Education is a future investment that is believed to improve the life of a nation. As a country that proceeds in the development of the modern era, Indonesia has a law on the national education system from an early age. It is stated that early childhood education is a coaching effort aimed at children from birth up to the age of six conducted through the provision of educational stimulation to assist growth and physical and spiritual development so that children have readiness in entering further education as a matter of support for the existence of early childhood education.

Early childhood education is the stage of education before elementary education, which in the process is carried out through the provision of stimulus or provision of education stimulation from birth to age of six to help the growth and development of physical motor, religion/spiritual value, cognitive, language, social emotion and art so that children have readiness in entering further education, on formal, non-formal, and informal education. Through the educational process, it is expected that aspects of 
development in children can be developed in accordance with the stages of child development. According to The Regulation of Ministry of Education and Culture, Republic of Indonesia No. 137 (2014) there are six aspects that must be developed for early childhood that is aspects of the development of religious and moral values, physicalmotor, cognitive, language, social-emotional, and art. By developing these aspects in addition to providing the child's readiness in adjusting environmental developments, it can also make children ready and feel easy to continue to the next stage of education. One of the six aspects above that needs to concerned is language development. According to Samapra (2005) language is one of the communication codes that are often used by humans in their lives, then understanding the meaning of words in the language to be the basic human need. This becomes one of the reasons why in early childhood education there is a concern of language learning and English is one of the languages that is taught to form the ability of students in facing the era of globalization.

To prepare children in this globalization era, they are equipped by English language competence. English as a foreign language taught in every level education and became one of the efforts in the formation of human resources that have more readiness in responding to global challenges. Understanding English is one of the goals in learning English. Children can be introduced by foreign language such as English. Therefore, English is offered from an early age, especially in early childhood education institutions. This introduction of English as a foreign language is based on the assumption that children can absorbs new vocabulary more quickly Therefore, children will learn faster foreign language than adults (Santrock, 2007). For example, a report from Zong \& Batalova (2017) showed that immigrants from China living in the United States around age of 5 over have English language proficiency less than those who was born and educated from early years. At the level of early childhood education especially in kindergartens, English language learning should be packed and served in a fun and interesting ways so that children do not find it difficult to understand the meaning of the given words. This idea was recommended because there are still lack of creativity of early childhood educators in providing materials so children lose their interest in learning language. The ability that Indonesian students must possess according to The Regulation of Ministry of Education and Culture, Republic of Indonesia is to understand and disclose information, thoughts, feelings, and develop science, technology and culture using English. Language, especially English, may be a medium or tool of communication in order to access information, foster interpersonal relationships and exchange information. Understanding vocabulary is one component of language learning.

From the results of observations that the author did in English language learning in group B TK Pertiwi 29 Semarang, it can be seen that there were children who have difficulty in understanding English vocabularies. Beside of vocabulary knowledge that is still minimal, their English pronunciation is often not correct. This is because English language learning is given by lecturing, the teacher just pronounce the English words then pronounce the meaning in Bahasa Indonesia. Learning in early childhood education is naturally presented by playing, fun, and using interesting media. This is in accordance with the principle of learning in early childhood education that is 'learn and play'. For that, English language learning should be made and designed in such a way that the child 
is interested to follow. Play is an activity that is very important for children. Play provides an element of fun and happiness for children. Play is a child's way to solve the problem. It is also a way of children to imitate the behavior of adults to reach maturity (Purboyo, 2004).

Play is beneficial for children to learn to communicate with their friends in terms of expressing their thoughts and feelings as well as understanding what their friends (Purboyo, 2004) are saying. It is also as a medium for children to learn the culture of social roles, and gender roles that take place in society. Teachers introduce English vocabulary with images that have been designed in the snake and ladder board game. Through this playing media, children are expected to be more eager to follow English language learning so that it can improve their early foreign language vocabulary, particularly in TK Pertiwi 29 Semarang. It has been described that English needs to be taught from an early age and should be conveyed with methods and instructional media that attract children's attention. The author feel interested in conducting research entitled 'Enhancing English Vocabulary through The Use of Snake and Ladder Media for 4 to 6Year-Old Children at Tk Pertiwi 29 Semarang'.

Based on the background and the identification of the problem, this research questions how can English vocabulary be enhanced through the use of snake and ladder media for children aged of $4-6$ in TK Pertiwi 29 Semarang. The objectives to be achieved in this study include: (a) general purpose, to find out the enhancement of English vocabulary of children through snake and ladder media; and (b) special purpose, to support the improvement of English language vocabulary of early childhood education by providing empirical data from group B TK Pertiwi 29 Semarang.

This research is grounded by the relevant research. Zubaidah's (2012) research was done with two cycles, data collection techniques from observation and documentation. Research conducted by Zubaidah gives an illustration that in cycle I only four people $(40 \%)$ who can count numbers from one to ten, while six people $(60 \%)$ still get less value. In the second cycle, an improvement of children who received good grades to nine people $(90 \%)$ and only one has not been successful due to the age factor that has not reached 5 years. Based on the results of this study, it can be concluded that the implementation of learning with the snake and ladder game can improve the intelligence of mathematical logic of children and proven effective. Therefore, this study that has similarity with previous relevant research in term of educational media become the complementary and representation of the research object that is used in this research. This study aims to improve the English proficiency of learners and changes in the behavior of English language learning in early childhood education, especially the age of $4-6$ in TK Pertiwi 29 Semarang.

\section{LITERATURE REVIEW}

Language is a system of communication, in which words and other forms of combination of other written symbols are ordered to produce a number of messages 
(Hetherington \& Parke, 1999). Language is a tool to communicate, express feelings or thoughts that contain certain meanings through either speech, writing or sign language / body language. Each language has certain rules and communications are said to be effective when people are invited to understand the message communicated by sources of communication. Language skills will develop according to the stage of children development (Rowe \& Zuckerman, 2016).

While the ability of language is the ability of a person in expressing a specific intent or communicate precisely and coherently so that others (Simin \& Tavakoli, 2014) can understand the message conveyed four components of language that should be notice such as: (a) phonology, the system of sounds used in language. Phonology in language consists of phonemes. The phoneme is part of the language phonetic system. The phoneme is the smallest part of a meaningful language unit; (b) semantics, learning the meaning of words and word combinations, such as phrases, clauses (clauses) and sentences; (c) Grammar: the structure of language, which consists of morphology and syntax. Morphology is the smallest part of a language that has a meaning like a morpheme. Syntax is part of the grammar that describes how to combine words into phrases, clauses and sentences; and (d) pragmatics, the rules of the language used in the social context, the knowledge that individuals have about the rules that underlie the use of language. Pragmatics includes not only about speaking and writing but also relating to how the source of communication expresses its language so that others can understand it (Hetherington \& Parke, 1999).

Therefore, in this study, language competence is described by the ability of an individual to make words or sounds that combined into an utterance / a unified whole sentence that can be understood by himself and others. It is also when the individual can understand speech / language that is conveyed by others and able to show / speak the language to others. The ability of early childhood language can be distinguished into two. First, first language, in the form of innate ability, is owned by everyone who emerged because of the stimulation of parents and the immediate environment such as family. (Dulay, Burt \& Krashen, 1982). While second language is the ability that is influenced by environmental language factors and internal factors / self. Environmental language factor is the environment where the majority of the second language is used, and internal factors are the willingness of the self to learn a second language. If in a school context, second language can be presented by English course or any other United Nations international language.

The word media comes from the Latin word 'medius' which means 'middle'. In general, media are all forms of intermediaries to spread, carry and convey something messages and ideas to the recipient (Azhar, 2007). The term of learning media has some understanding. Gerlach \& Ely (1971) stated that learning media is not just tools but also the user of the tools that deliver the messages or information. The main purpose of using instructional media is to communicate easily so that students are able to absorb the material provided as much as possible as the recipient of information. Thus, the information will be faster and easier to be processed by learners without having to go through a long process that will make it saturated. 
Snake and ladder media is a board game for children that can be played two or more people. The accessory is divided into small boxes and in some cities, there are a number of pictures of 'ladders' and 'snakes' that connect with other boxes. The snake and ladder is a game that uses dice to determine how many steps a pawn should take. These games fall into the category of board game or similar to monopoly games, halma, ludo, and so forth. The board is a plot of 10 rows and 10 columns with 1-100 numbers, as well as snake and ladder pictures (Husna, 2009). The snake and ladder game is included in game media. Sadiman (2003) stated that games are every contest of players who interact with each other by following certain rules to achieve certain goals. In accordance with that opinion, Sadiman (2003) added that every game must have the main components namely: (a) the presence of players; (b) the existence of an environment for the player to interact; (c) the existence of the rules of the game; and (d) the existence of certain desired goals.

The snake and ladder is a game and media that cannot be separated from the pictures or photos that are on the board of the snake and ladder itself, such as snake and staircase images, or other images according to the snake and ladder theme. Images or photos serve to convey messages that involve the sense of sight so as to attract attention, illustrate facts or information (Kustandi \& Sutjipto, 2011). Based on the characteristics of the game is done on the board then the players take turns running each other; the rule of the game is the game using dice and paw according to the number of players. The player starts from the first plot and takes turns throwing dice, the pawn is executed according to the dice eye that appears, the pawns are at the bottom of the ladder directly up to the landing, and the pawn at the end of the snake directly down toward the head of the snake. There is a certain goal to be achieved that is the winner of the game is the player who first reached the last plot.

However, unlike the concept of snake and ladder game that will be applied to this research. The snake and ladder in this study did not use a system that achieved the highest number to win. The system is transformed into a child who can answer the most questions on the landing boards will get the highest point. In addition, it will be provided by the assistance in the form of words and pictures to help children answer questions when students encounter difficulties in playing snake and ladder. Not all systems in the game are changed because the snake and ladder system remain in the game. The rules of dice shaking also remain the same as the snake and ladder game that is usually played. This game has once used by Wulansari \& Azizah (2018) and showed the result of children's English vocabulary improvement. Language skill development in kindergarten is perceived as an important matter because language is used to think, observe, speak, read, and write.

Early childhood vocabulary can be developed through image media transformed in snake and ladder media. Playing snakes and ladder can stimulate children's language intelligence through the activity of identifying images and writing in the context of the word. In addition, children's interpersonal intelligence will also be raised through teamwork. The use of helping tools as well as technology, in recent research findings, maximize the material to be learned and are able to make students shape their learning 
habit or also known as habituation especially in enhancing language competence in teaching learning process (Kurniawan \& Tanone, 2017).

Before doing the activity, the teacher needs to prepare all the equipment used in the game. The equipment includes game boards of ladder and snakes, dice, and pawns to play. Each game has its own rules. Therefore, a set of rules and procedures for playing a snake and ladder among others: (a) all players start the game from plot number 1 and ends in plot number 25; (b) there are some number of snakes and ladders located on a particular plot on the game board: (c) there is 1 piece of dice and several pieces of pawns. The number of pawns used corresponds to the number of players. Usually pawns use different colors for each player, there are no specific rules for the type of pawn that should be used; (d) the length of the snake and the ladder vary, the snake can move the piece of the player backwards some plot, while the ladder can move the player forward several plots; (e) some of the snakes and ladder are short, and only a few long ladder; (f) to determine who gets first turn, throwing dice by every player, who gets the highest score is who gets first turn; (g) all players start the game from plot number 1; (h) at the turn, the player rolls the dice and can advance at least several plots according to the number of dice throws; (i) if the dice shows the number 6 , then the player gets a chance to run the pawns as much as six steps and roll the dice back; (j) there may be more than one piece on one plot; (k) if the player's pawn ends on a plot that arrives at the foot of the ladder, then it goes up at the top of the ladder; (1) if the player's pawn ends in a plot with a snake tail image, then it must descend to the plot designated by the head of the snake; and $(\mathrm{m})$ the winner of this game is the player who earns the highest score when he / she answers the question and the game ends if there is a first successful reach to plot number 25 .

In general, games used in learning have several benefits. First, provide knowledge to children through the learning process of playing while learning. Second, stimulate the development of thinking power, creativity, and language in order to foster good attitude, mentality, and morals. Third, creating an exciting, comforting, and enjoyable playing environment. Then, improving the quality of children's learning in physical, motor, linguistic, intellectual, moral, social, and emotional development (Ismail, 2012). In addition to learning, games are also related to child development as states by Riva (2012) that there are nine benefits of snake and ladder playing media. Those are (a) train motor skills, (b) train concentration, (c) increased socialization skills, (d) practice language skills, (e) add insight, (f) developing the ability to problem solving, (g) develop a leadership spirit, (h) develop knowledge of norms and values, and (i) increase confidence.

This opinion is complemented by the Yeti's (2007) opinion which states that in particular the instructional medium of snake ladder in learning has several benefits. First, it can create a fun learning atmosphere. Second, it stimulate the child in doing individual learning activities or groups. Then, it can develop creativity, independence of children create mutual communication and can foster responsibility. The last one is the cognitive structure obtained as a result of meaningful learning process will be stable and arranged in the relevant so that will be maintained in the memory. This will make it easier for children to recall what they have learned. 
Based on the description of the benefits of the snake ladder game, it is concluded that the game used in learning is useful to improve the physical-motor, linguistic, intellectual, moral, social, and emotional development of students, so that the ladder snake game can be a fun learning media and develop student attitudes about the rules. If the media play, a ladder snake applied to the learning of English early childhood vocabulary in TK Pertiwi 29 Semarang then the ability of children in understanding English vocabulary will increase. In addition, the attitude of learners will change to a more positive direction.

\section{RESEARCH METHOD}

This research uses Classroom Action Research (PTK) to improve the quality of learning and help empowering teachers in solving learning problems in school (Masnur, 2012). The research used the design of PTK with two cycles. First, the process of action in Cycle I is to know the ability to present the summary of the text of the observation result of the students. Then, Cycle II is used to find out the ability to present a summary of the text of the observation result after the improvement in teaching and learning activities in Cycle I. Each cycle has four stages: (a) planning; (b) action; (c) observations; (d) and reflection. The cycle description is shown in Figure 1 (Arikunto, 2007).

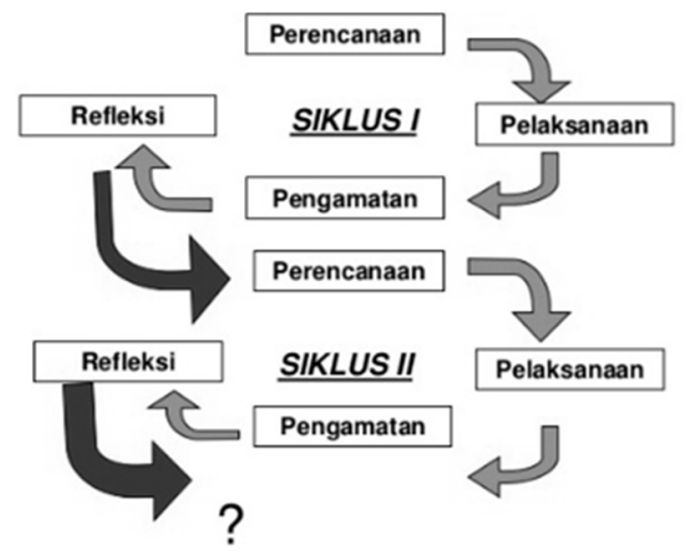

Figure 1. Arikunto’s Classroom Action Research Cycle

The data used in this research are: (a) qualitative descriptive data, in the form of vocabulary; and (b) quantitative descriptive data, in the form of calculation of children's English vocabulary improvement. This research has generalization target from research sample that is population (Arikunto, 2007), which is 20 student of group B TK Pertiwi 29 Semarang.

To determine the success and effectiveness of this study, the performance indicators are formulated and used as reference of success. The indicator of success is the improvement of English vocabulary mastery of early childhood students, especially group B kindergarten (age 4 - 6 years) in the class by reaching 75\%. Since a percentage below 
$50 \%$ is a process failure. It is said by 'accomplished' if the result reach $75 \%$ because it is based on the KKM value. Therefore, if the KKM has been achieved in $75 \%$ of all the students it can be said that the research is successful.

The instrument used is a non-test instrument in the form of observation sheet to find out the improvement of children's English vocabulary mastery by using snake and ladder media. The filling of the observation sheet is done by: (a) determining the indicator to be used for snake and ladder media; and (b) describe the indicators into the items indicating the achievement of the indicators that the child can perform when carrying out the activities. An observation point from the translation of indicators is seen in Appendix 1 .

Data gathering in this study was conducted by observation, interview and documentation. Observation by looking closer at any ongoing incident and recording it by means of observation about things to be observed or researched (Wina, 2009). The interviews and discussions was done to obtain information on matters relating to the implementation of early childhood vocabulary learning. Finally, documentation was conducted to obtain school data and student name of Group B TK Pertiwi 29 in the form of photograph and recording of learning process of English vocabulary with play media of snake and ladder.

\section{RESULTS AND DISCUSSION}

Teaching learning process in TK Pertiwi 29 Semarang based on curriculum of Minister of Education and Culture, Republic of Indonesia. Aspects developed include some of the development of religious and moral values, physical motor (which includes gross motor and fine motor), cognitive (consisting of general knowledge and science, the concept of size, color, and pattern, and the concept of numbers, symbols of numbers and letters), language (consisting of accepting language, expressing language, and literacy), and emotional social, and self-reliance.

The field of language development including national language of Indonesia and English as a foreign language. English learning in TK Pertiwi 29 Semarang is still limited to the vocabulary learning and short sentences spoken daily, such as "good morning!", "How are you?" and others. The method used is usually a question and answer, and repetition of the vocabulary that has been spoken by teacher. The teacher just said the word in Indonesian and then pronounced in English and the child is asked to imitate. English learning has also not been using media or any supporting properties

In general, children are demanded to join English language learning. However, some children are less interested in it. They first know English in school with question and answer method and without using media. The author conducted the English language learning on March 26 to March 31, 2018, this was done to know the mastery of children's English in kindergarten Group B. Researchers began the teaching learning process by inviting children to sing 'Here is A Boat' to recognize the names of each child. The song was sung in rotation based on who is chosen, when it was sung several times, some 
children were able to follow. Some new children memorized some, and some children were silent and did not involve in learning. After the song was finished, the researcher provided some vocabulary in Indonesian and asked the English version from the children. Some words could be answered correctly by the children like the word 'cat', and 'dog"'. This is because teacher in class often uses animal vocabulary so children are familiar to hear those words. Seventeen children can only answer the proposed vocabulary from twenty children in group B. Figure 2 is a graph of the initial reflection results used as a pre-cycle data.

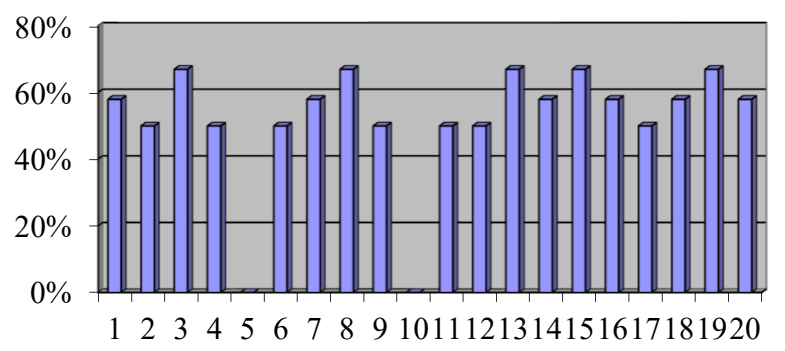

Figure 2. Children's English Competence in Pre-Cycle

From the result, it is known that the capability of children to learning English ability reaches an average of $52 \%$. From the data above, it can be said that the status of achievement for 20 students has not been achieved well because it is still below $75 \%$.

Researchers observed children who have not focused on the process of learning English. The low percentage of achievement happened because researchers had not used interesting properties or attractive learning media. Researchers discussed with classroom teachers what steps that need to be taken for future learning. Based on the results of discussions and interviews, researchers needed to take steps to improve the quality of English language learning, in particular, improvement of English vocabulary. Researchers agreed to implement Cycle I action on March 27, 2018.

\section{The Process Of Action Research In English Language Learning (Cycle I)}

Action planning was conducted on March 27, 2018 at TK Pertiwi 29 Semarang. On the venue, the researcher discussed with classroom teacher about the activities that will be done in Cycle I. Things discussed are making a similar perception and agreement about the research that will be conducted. Then, proposing English language learning through snake and ladder playing media by doing lesson planning. Next, proposing observation sheet in the form of checklist as instrument of assessment of English vocabulary improvement, and determine the schedule of action execution. At the discussion, it was agreed that the researcher played a role as the implementation of action and teachers played a role as observer. Allocation of time is about 150 minutes each meeting. The action in Cycle I will be implemented on March 27, 2018. From the results of the action in the Cycle I that has been implemented, researcher obtained data presented in Figure 3. 


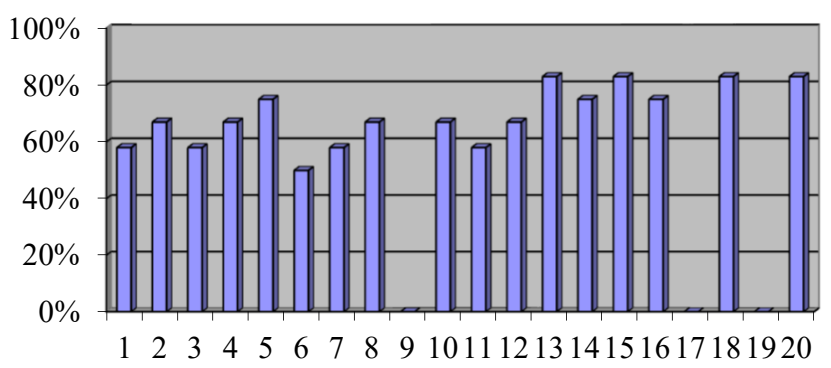

Figure 3. Children's English Competence in Cycle I

Based on the results of the action in Cycle I, the researchers analyzed the learning process and improvement of English vocabulary mastery. The improvement in the results of the action in Cycle I showed a result an average of of 59\%. It was increased $7 \%$ from pre-cycle stage. It can be said that 7 out of 20 students were fulfilled the criteria of achievement though more than a half were still below the criteria.

Based on that result, it can be said there has been an increase in English vocabulary mastery of children when compared with the mastery before the action, but the results are not maximized. The reflection from Cycle I resulted some problems such as : (1) the division of group members was too much so that the game was less effective because children played with great enthusiasm resulting noisy environment and there are children who were helped by other children ; (2) the improvement of students' English vocabulary mastery in a class is not evenly distributed, there were still children with high and low ability rank ; (3) there was vocabularies that are easy to remember and some others are difficult. From the results of the analysis, the researcher felt that the results of the study has not been maximized. Therefore, the researcher made a reflection and planned for further action in the next cycle

\section{The Process Of Action Research In English Language Learning (Cycle II)}

English learning process that has been done in Cycle I generally was good enough but it was not yet fulfill the indicator of success that is $75 \%$. There were still children who have not reached the percentage of the determined success. To overcome the shortcomings in Cycle I, then on Thursday, March 29, 2018 researcher planned the action for Cycle II.

Researcher did some things that should be done in learning. These were: (1) maximizing the action of interacting with the students, motivating, and strengthening; (2) providing activities in the form of worksheet because there were children who were too active if only given the activity of playing with the games and there were children who were calmly playing while waiting the turn so all children are expected to be calm and able to wait the turn neatly; and (3) spurring the spirit by giving a reward in the form of stamp to children who successfully answered the question. Generally, further teaching learning process in Cycle II as mentioned above was quite similar to the learning process in Cycle I. From the results of action in the cycle II that has been implemented, researcher obtained data presented in Figure 4. 


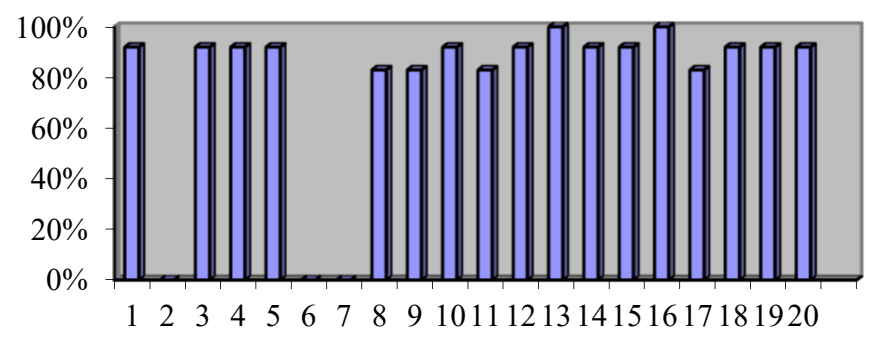

Figure 4. Children's English Competence in Cycle II

The process of the action in Cycle II went well and smoothly. Weaknesses that exist in Cycle I can be resolved although it was not optimal. It made the quality of English language learning in that class increased. The enhancement of learning quality could be seen from the achievement result that is clearly visible from children's English vocabulary mastery in Cycle I and Cycle II. In Cycle I the achievement was at the average of 59\% and Cycle II, it reached $77 \%$. Hence, the action applied in English language learning in group B TK Pertiwi 29 Semarang succeeds because it has been beyond the minimum limit of achievement that is $75 \%$. Based on the results of data collection from Pre-Cycle to Cycle II, the improvement of students' English vocabulary mastery can be described by Figure 5 below.

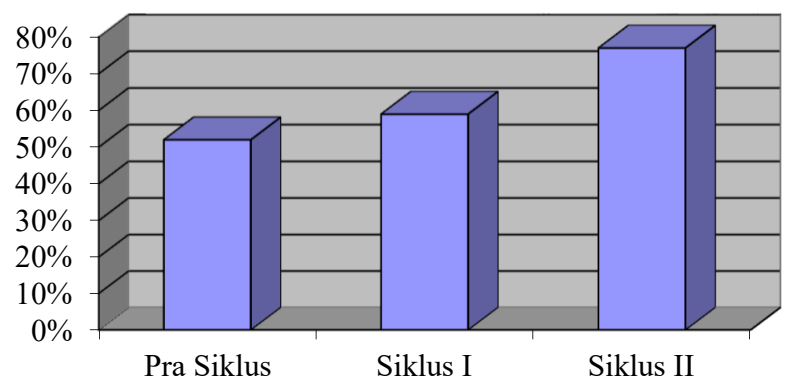

Figure 5. Enhancement of English Vocabulary Mastery from Pre-Cycle to Cycle II.

Based on Figure 5 presented, it can be seen that children's English vocabulary mastery from Pre-Cycle to Cycle II showed any improvements. In Pre-Cycle stage, the achievement was at the average 52\%. Then, improvement happened in Cycle I which the achievement reached 59\%. The last stage (Cycle II), it reached 77\%. Based on the analysis conducted by the researcher, the enhancement of student competence especially for vocabulary mastery is influenced by snake and ladder game board applied in English language learning. Playing snake and ladder is an appropriate learning strategy for early childhood because by playing it children can easily absorb the lesson. With a fun atmosphere provided, children are actively involved in teaching learning process.

Through snake and ladder media, children easily absorb English language learning and the improvement of children's vocabulary is at the optimal point. Children need to 
play because in the play, children can find the knowledge of social world that later became part of children's thinking and intention of problem solving as well as a readiness to use language to communicate with people around. When children play a game designed in line with the material given, they will learn unconsciously and tend to repeat the game as a habit. This idea is in accordance with the result of Kurniawan \& Tanone's (2017) research finding. The soft force of this habituation through helping tools and technology helps students to learn language more effectively. The more children learn in an interesting way with a good framework of language learning model, the more knowledge that children will learn and gain. Again, playing is a good way to be a part of learning media in English language learning as what was proved from research result of Ndraha \& Kurniawan (2019) that play can bring a positive impact and help student to be involved in English language learning. Similar to that, snake and ladder game affected positively to children's English ability development.

Therefore, instructional media becomes one of important things in providing children with learning and playing. The enhancement of children's English vocabulary mastery is also affected by the changing of situation as the result of Cycle I reflection. The development of learning quality through problem solving give a positive contribution especially when interesting and attractive learning media in teaching foreign language to children support the development.

\section{CONCLUSION}

Based on the results of classroom research conducted by implementing several actions from cycle I to cycle II and from the results of all the discussions and analysis that have been done can be drawn conclusions as follows: (a) snake and ladder media can enhance the children's English vocabulary mastery which is indicated from the improvement of the average achievement percentage from pre-cycle to Cycle II, i.e. Average percentage of $52 \%$ in Pre-Cycle, $59 \%$ as the result of Cycle I and $77 \%$ as the result of Cycle II; and (b) the use of snake and ladder media is an effective learning strategy to improve the understanding of early childhood English learning. It is because the snake and ladder media is in accordance with the principles of early childhood teaching and learning which is playing while learning and learning while playing. Children can develop their knowledge and social interaction with their friends freely without burden and children feel happy learning English by playing an interesting media. This encourages children to participate actively in learning and make the instructional games become a positive tool shaping learning habit.

Thus, teachers should use appropriate learning strategies, which can attract children's attention. It also need to be fun in order to make teaching learning process interesting so it will encourage children's interest and enthusiasm in achieving learning goals, particularly English language vocabulary. Since snake and ladder media can improve children's English vocabulary mastery, teachers should apply this media and approach emotionally to children so they feel happy and comfortable while following the lesson. In addition, parents should always support their children with various efforts, 
especially to develop children language competence. Parents can take advantage of the surrounding environment as a medium to develop children language competence, especially English as a foreign language.

\section{REFERENCES}

Arikunto, Suharsimi, \& Supardi. (2007). Penelitian Tindakan Kelas. Jakarta: Bumi Aksara.

Azhar, A. (2007). Media Pembelajaran. Jakarta: raja grafindo persada.

Dulay, H., Burt, M., \& Krashen, S. (1982). Language Two. Oxford University Press.

Gable, S., Belsky, J., \& Crnic, K. (1992). Marriage, Parenting, and Child Development: Progress and Prospects. Journal of Family Psychology, 5(3-4), 276-294.

Gerlach, \& Ely. (1971). Teaching \& Media: A Systematic Approach. Boston: Allyn and Bacon.

Hetherington, E., \& Parke, R. (1999). Child Psychology. Pennsylvania: McGraw-Hill College.

Husna, M. (2009). 100+ Permainan Tradisional Indinesia Untuk Kreativitas, Ketangkasan, Dan Keakraban. Yogyakarta: Andi.

Ismail, A. (2012). Edukatif Games. Yogyakarta: Pro-U Media.

Kurniawan, M., \& Tanone, R. (2017). Mobile Learning in TESOL: A Golden Bridge for Enhancement of Grammar Awareness and Vocabulary Master? Asian EFL Journal, Research Edition, 8(1), 155 - 159.

Kustandi, C., \& Sutjipto, B. (2011). Media Pembelajaran; Manual dan Digital. Bogor: Ghalia Indonesia.

Masnur, M. (2012). Melaksanakan PTK itu Mudah . Jakarta: Bumi Aksara.

Purboyo, K. (2004). Memilih, Menyusun Dan Menyajikan Cerita Untuk Anak Usia Dini. Yogyakarta: Tiara Wacana.

Riva, I. (2012). Koleksi Games Edukatif di Dalam dan di Luar Sekolah . Jogjakarta: FlashBooks.

Rowe, M.L., \& Zuckerman, B. (2016). Word gap redux: Developmental sequence and quality. JAMA Pediatrics, 170(9), 827-828. doi: 10.1001/jamapediatrics.2016.1360.

Sadiman, A. (2003). Media Pendidikan. Jakarta: Raja Grafindo Persada.

Simin, S. \& Tavakoli, M. (2014). Assessing Speaking Ability in Academic Context: Focusing on a Mixed Methods Approach. International Journal of Research Studies in Language Learning. Volume 4 Number 1, January 2015, pp.71-81

Samapra, K. (2005). Kadhipta. Jakarta: Balai pustaka.

Santrock, J. (2007). Psikologi Perkembangan. Jakarta: Erlangga. 
The Regulation of Ministry of Education and Culture, Republic of Indonesia Number 137 (2014). National Standard of Early Childhood Education.

Ndraha, V.E., \& Kurniawan, M. (2019). Playing "CABE" (Searching and Whispering) to Increase Children's English Vocabulary. Jurnal Pendidikan Usia Dini, 13 (1), 143 - 157. https://doi.org/https://doi.org/10.21009/10.21009/JPUD.131.11

Wina, S. (2009). Strategi Pembelajaran Berorientasi Standar Proses Pendidikan. Jakarta: Kencana Prenada Media Group.

Wulansari, M. \& Azizah, N. (2018). Language Skill Development in Kindergarten is An Important Matter because Language is Used to Think, Observe, Speak, Read, and Write. Advances in Social Science, Education and Humanities Research, Volume 249.

Yeti, M. (2007). Ketrampilan Berbahasa Indonesia SD. Jakarta: Universitas Terbuka.

Zong, J. \& Batalova, J. (2017). Chinese Immigrants in the United States. The Online Journal of The Migration Policy Institute. Taken From: https://www.migrationpolicy.org/article/chinese-immigrants-united-states

Zubaidah. (2012). Peningkatan Keaktifan Belajar Matematika Melalui Model Pembelajaran Tematik Pada Siswa Kelas II Semester I SD Negri Kayen 05 Kecamatan Kayen Kabupaten Pati Tahun Pelajaran 2012/2013. Universitas Muhammadiyah Surakarta.

\section{APPENDIX}

Table 1. Point of Observation in Research Observation Sheet

\begin{tabular}{|c|c|c|c|}
\hline No & Indicator & Point of Observation & Scores \\
\hline \multirow[t]{2}{*}{1} & \multirow[t]{2}{*}{$\begin{array}{l}\text { Imitate and distinguish } \\
\text { certain sounds. }\end{array}$} & $\begin{array}{l}\text { Children can imitate vocabulary } \\
\text { in English. }\end{array}$ & $\begin{array}{l}3 \text { = Child can imitate the } \\
\text { vocabulary in English correctly. } \\
2 \text { = Child can imitate vocabulary } \\
\text { in English with help. } \\
1 \text { = Child can not imitate } \\
\text { vocabulary in English. }\end{array}$ \\
\hline & & $\begin{array}{l}\text { The child can interpret the word in } \\
\text { English. }\end{array}$ & $\begin{array}{l}3=\text { Child can correctly interpret } \\
\text { the word in English. } \\
2=\text { Child can interpret the word } \\
\text { in English with help. } \\
1=\text { Child cannot interpret the } \\
\text { word in English. }\end{array}$ \\
\hline 2 & $\begin{array}{l}\text { Shows some of the } \\
\text { requested images. }\end{array}$ & $\begin{array}{l}\text { The child can show the requested } \\
\text { picture in accordance with } \\
\text { English. }\end{array}$ & $\begin{array}{l}3=\text { Child can show requested } \\
\text { picture with English correctly. } \\
2=\text { Child can show requested } \\
\text { pictures in English with help. } \\
1=\text { Child can not show requested } \\
\text { images in English. }\end{array}$ \\
\hline 3 & $\begin{array}{l}\text { Pronouncing English } \\
\text { vocabulary in Snake } \\
\text { and Ladder media }\end{array}$ & $\begin{array}{l}\text { The child can pronounce the name } \\
\text { of the animal in English according } \\
\text { to the image in the snake and } \\
\text { ladder media. }\end{array}$ & $\begin{array}{l}3=\text { Child can pronunce the name } \\
\text { of the animal in English } \\
\text { according to the image on snake } \\
\text { and ladder media correctly. } \\
2=\text { Child can pronunce the name } \\
\text { of the animal in English }\end{array}$ \\
\hline
\end{tabular}




\begin{tabular}{|l|l|l|}
\hline & $\begin{array}{l}\text { according to the image on snake } \\
\text { and ladder media with help. } \\
1=\text { Child can not pronunce the } \\
\text { name of the animal in English } \\
\text { according to the image on snake } \\
\text { and ladder media. }\end{array}$ \\
\hline
\end{tabular}

The guidelines for filling in the observation sheet are as follows:

a) Determining items of observation by giving scores with the following conditions: $3=$ if the child can do without help

$2=$ if the child can do with help

$1=$ if the child cannot do

b) Create an observation sheet that is used to record the observations of each action. The observation sheet consists of student name, group / semester, indicator, item of observation, amount of grain of observation that can be done.

c) Conducting observations by checking the checklist (v) on the column. 